\title{
Infection biology as the basis of integrated control of apple canker (Neonectria ditissima) in Northern Europe
}

\author{
Roland W. S. Weber ${ }^{1,2^{*}}$ (1) and Jorunn Børve ${ }^{3}$
}

\begin{abstract}
Background: European canker, caused by Neonectria ditissima, is a disease of worldwide importance in apple production, yet knowledge about it is limited, highly regional and sometimes contradictory. This is an obstacle to successful disease management. Key aspects for Northern Europe are reviewed, based on research results from Northern Germany and Norway and on international literature data.

Main topics: Trunk cankers developing on young trees within the first 1-3 seasons of explanting can often be traced back to latent infections initiated in the nurseries. The most important nursery infection is a lateral canker on the main trunk of 'knip'trees, which are the standard tree type in Northern Europe. In strongly affected batches, up to 25\% of trees have to be uprooted after the first growing season due to such trunk cankers. The establishment and maintenance of healthy orchards requires clean nursery material, especially in the case of susceptible cultivars. In Northern Germany, infections within commercial orchards most often proceed through wounds caused by fruit picking or leaf fall in autumn, as shown by the appearance of cankers in the following spring and by the high efficacy of fungicide treatments at leaf fall. Ascospores, commonly thought to be relevant for long-distance spread of infections, are not released until the end of leaf fall even in wet autumn seasons in Northern Germany. Therefore, their role in the disease remains unclear. Strong nitrogen-induced vegetative growth favours apple canker. In field trials conducted under conditions of current commercial practices, autumnal sprays with copper hydroxide or copper oxide were consistently more efficacious than copper oxychloride or captan in preventing new infections.

Conclusions: Restricted fertilisation and other measures to curb excessive vegetative growth during the first few years of an orchard, repeated canker pruning and well-timed treatments with effective fungicides in autumn are essential for IPM of apple canker. Nonetheless, canker remains capable of severely impairing the commercial success of susceptible cultivars in regions with wet climates even if all available measures are taken. This opens up long-term perspectives for the breeding of more resistant cultivars.
\end{abstract}

Keywords: Ascospores, Canker pruning, Conidia, Copper hydroxide, Fertilisation, Fungicides, Latent infection, Neonectria ditissima, Nursery, Prohexadione calcium, Root pruning

*Correspondence: roland.weber@lwk-niedersachsen.de

1 Landwirtschaftskammer Niedersachsen, Esteburg Obstbauzentrum Jork, Moorende 53, 21635 Jork, Germany

Full list of author information is available at the end of the article

\section{Background}

Canker of fruit trees, caused by Neonectria ditissima (syn. N. galligena), is one of the major diseases of apple (Malus domestica) worldwide (Creemers 2014). Pear (Pyrus communis) and quince (Cydonia oblonga) as well as a wide range of broad-leaved forest tree species

c) The Author(s) 2021. This article is licensed under a Creative Commons Attribution 4.0 International License, which permits use, sharing, adaptation, distribution and reproduction in any medium or format, as long as you give appropriate credit to the original author(s) and the source, provide a link to the Creative Commons licence, and indicate if changes were made. The images or other third party material in this article are included in the article's Creative Commons licence, unless indicated otherwise in a credit line to the material. If material is not included in the article's Creative Commons licence and your intended use is not permitted by statutory regulation or exceeds the permitted use, you will need to obtain permission directly from the copyright holder. To view a copy of this licence, visit http://creativeco mmons.org/licenses/by/4.0/. The Creative Commons Public Domain Dedication waiver (http://creativecommons.org/publicdomain/ zero/1.0/) applies to the data made available in this article, unless otherwise stated in a credit line to the data. 
may also be affected, including many species growing in windbreaks and elsewhere in the immediate vicinity of orchards (Flack and Swinburne 1977; Walter et al. 2015a). Infections are seen on trunks, branches and twigs which become girdled, ultimately leading to the death of all organs distal to the infection site. Cankers often become delimited by callus tissue produced by the host plant in an effort to contain the infection. In addition, $N$. ditissima can cause fruit rots of apple which become visible as a blossom-end rot during the growing season or as a storage rot after harvest (Xu and Robinson 2010; Weber and Dralle 2013; Weber 2014).

Apple canker is particularly common in regions with a mild and humid climate, such as Northern Europe or New Zealand. Even within delimited geographic areas such as the Lower Elbe region of Northern Germany, there is a correlation of disease severity with annual rainfall (Saure 1961). This may mean that a highly susceptible cultivar is economically non-viable in one place whilst posing fewer problems some $50 \mathrm{~km}$ further east, or it may render a cultivar suitable for integrated but not for organic production in a given location. However, in comparison to the apple scab fungus (Venturia inaequalis) which infects leaves or fruit according to universally applicable rules of rainfall and surface wetness (MacHardy 1996), knowledge about canker is more regional and less complete, as will become apparent in this review.

Infections of $N$. ditissima can be caused by two spore stages. Asexual spores (conidia) are produced on cushion-like structures (sporodochia) throughout the vegetation period, i.e. between bud break and leaf fall. They are released by rainsplash, i.e. carried within small water droplets that are rebounded when a large rain drop hits a sporodochium, or by water run-off. The sexual ascospores are either distributed by wind, following their explosive release from perithecia, or by rainsplash or runoff if they fail to clear the perithecial ostiole in the discharge process, as shown in Fig. 1. Thus, only ascospores enable the fungus to undergo long-distance dispersal whereas both ascospores and conidia may spread the fungus within an infected tree or between adjacent trees. It is known that numerous spores-in the order of 10 to 100-of either type are required to establish a successful infection (Dubin and English 1974; Xu et al. 1998; Walter et al. 2016; Wenneker et al. 2017). The fungus requires fresh natural or artificial wounds as entry sites (Xu et al. 1998; Alves and Nunes 2017). The availability of wounds and spores is subject to immense variation throughout the year, between years and between different regions. This probably accounts for many of the differences in approaches to $N$. ditissima that exist between fruit production regions.

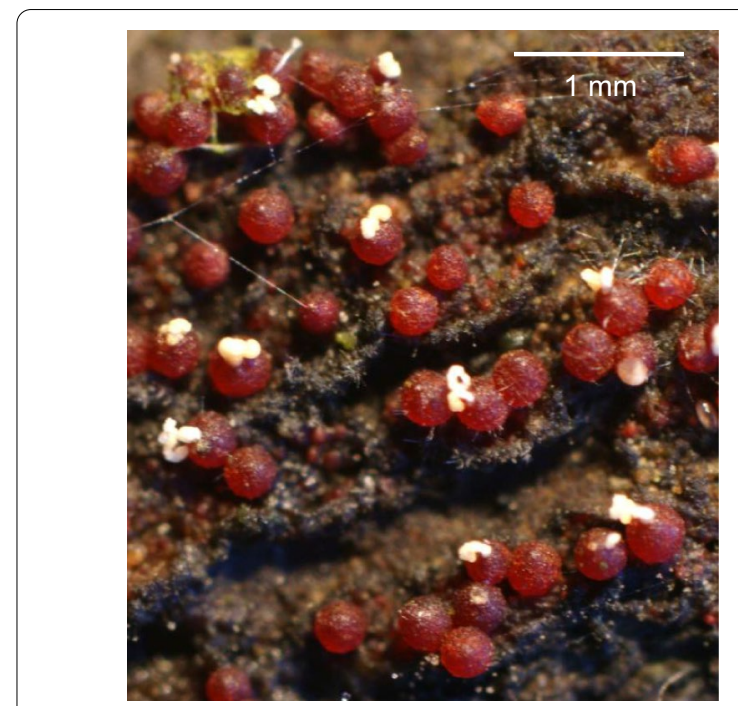

Fig. 1 Mature perithecia of Neonectria ditissima, some with a white cirrhus of ascospores at the ostiole. Small, more brightly coloured perithecium initials are also visible. Photographed on 30 Dec. 2013

A comprehensive recent review of apple canker has been written by Saville and Olivieri (2019). Aspects of the infection biology of $N$. ditissima in Northern Europe have been summarised by Swinburne (1975) and Weber (2014). In the latter review, areas of deficit in our current understanding of apple canker in Northern Europe were highlighted, including the role of ascospores in the infection biology of $N$. ditissima, relationships between tree growth vigour and canker, the role of nursery infections, and a practical evaluation of copper-based fungicides. In subsequent years we have conducted two joint research projects in Norway and Northern Germany to address several of these issues. In the present article we review progress in our understanding of the disease and its management, augmenting our own findings with recently published research results from other apple-growing regions. An outstanding series of publications on apple canker has come from New Zealand scientists, and this is valuable to Northern Europe not least because New Zealand is similar in climate and many details of apple production.

\section{The role of ascospores in Northern Europe}

In Northern Germany (Kennel 1963) and New Zealand (Amponsah et al. 2015), cankers usually become visible within a few weeks following an infection during the vegetation period, or a few months if the incubation time spans the dormancy period in winter. Under practical fruit production conditions in Northern Germany, by far the greatest numbers of canker lesions are due to wound infections dating back to harvest 
(picking scars caused by detachment of fruit stalks) or leaf fall (leaf scars), and these emerge in the following season around tree flowering. Depending on weather conditions, conidia are produced within a few days or weeks of canker symptoms developing. In contrast, at least in Northern Germany ascospore-releasing perithecia are rarely produced before autumn of the year in which the canker has appeared (Kennel 1963; Weber 2014). It is far from clear in Northern Europe whether ascospores are released primarily in autumn or in spring. This question is of great practical interest because airborne ascospores are considered to be the main agent by which infections can spread to previously disease-free orchards (Swinburne 1971). Therefore, in the orchards belonging to the Esteburg Fruit Research and Advisory Centre in Northern Germany we followed the emergence and development of perithecia on previously selected cankers at weekly intervals from autumn onwards, recording the percentage of cankers with mature perithecia. These were recognised by their fully expanded size, the differentiation of an ostiole, and the presence of ascospores in microscopic squash preparations or as white cirrhi above the ostiole (Fig. 1). Further, as soon as the first ripening perithecia were observed, approx. 80 cankers bearing them were collected from a heavily infected orchard, and placed around a rotating spore trap (Myco-Trap; Paul Illi, Wädenswil, Switzerland; Fig. 2) which continuously recorded spore catches from autumn through to late spring by which time perithecia showed signs of degeneration by turning dark brown and ceasing to produce ascospores. This development of perithecia

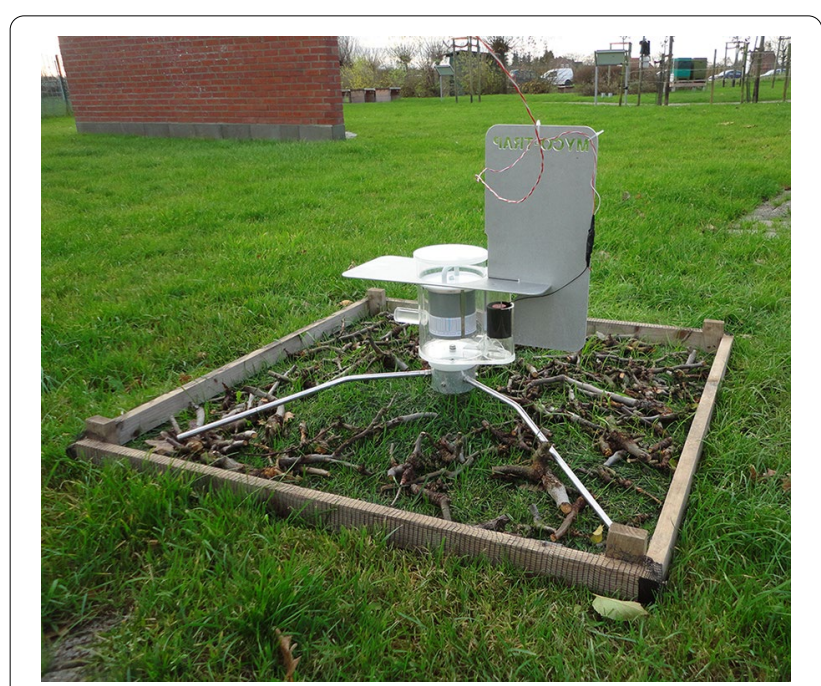

Fig. 2 Spore trap used for ascospore release studies in Northern Germany was indistinguishable in sequence and timing from that on cankers that had remained attached to trees in the orchard of origin.

Although these measurements are still ongoing, there are already some preliminary results of interest in the current context (Fig. 3). Following an unusually wet summer 2017 which produced $517 \mathrm{~mm}$ rainfall between June and November, as compared to the 30-year average of $416 \mathrm{~mm}$, perithecial maturation began well before leaf fall of the main cultivars at the Esteburg site, and mature perithecia were observed until the end of April 2018. However, whereas the first ascospores were recorded towards the end of leaf fall, the bulk of them was not released until late January through to April. In particular, we recorded a massive ascospore discharge on 5 March 2018 , i.e. within $24 \mathrm{~h}$ of the end of an eight-day period of severe continuous frost. Clearly, perithecia are overwintering structures of $N$. ditissima, and ascospore discharge on frosty days has been documented by Lortie and Kuntz (1963), albeit at low levels compared to frost-free periods. Rapid ascospore discharges upon thawing after prolonged freezing have been reported by Crane et al. (2009) for Neonectria fuckeliana, and by Trese et al. (1980) for Eutypa lata (syn. E. armeniacae), a canker and dieback pathogen of grapevine. Further, ascospores of E. lata retained their viability after repeated freezing-thawing cycles (Trese et al. 1980). In this context, Scheper et al. (2015) and Orchard et al. (2018) found for N. ditissima that aqueous conidial suspensions, too, can survive freezing and thawing without losing the ability to infect apple wounds.

The 2018 season was exceptionally dry $(215 \mathrm{~mm}$ between June and October), and perithecial maturation as well as ascospore discharge did not commence until late January, i.e. well after the end of leaf fall. As in the previous year, no mature perithecia were seen after April. The conclusion must be that in both these two years covering between them the current extremes of humidity regimes in Northern German summers, most ascospores were released too late for fruit scar or leaf scar infections but would have been available for infections of pruning wounds from late winter onwards, and of natural wounds in spring, i.e. at the same time as ascospores of $V$. inaequalis. This is surprising because autumnal leaf scars are a major starting point of new canker infections at least in Northern German commercial fruit orchards (Weber 2014) and fungicide sprays at leaf fall are indispensable for canker control in Northern Germany, New Zealand and elsewhere (see below). Further, early spring wounds such as bud scale scars or basal leaf scars are considered less susceptible to canker than pruning wounds, fruit picking wounds or autumnal leaf scars in Northern Germany 


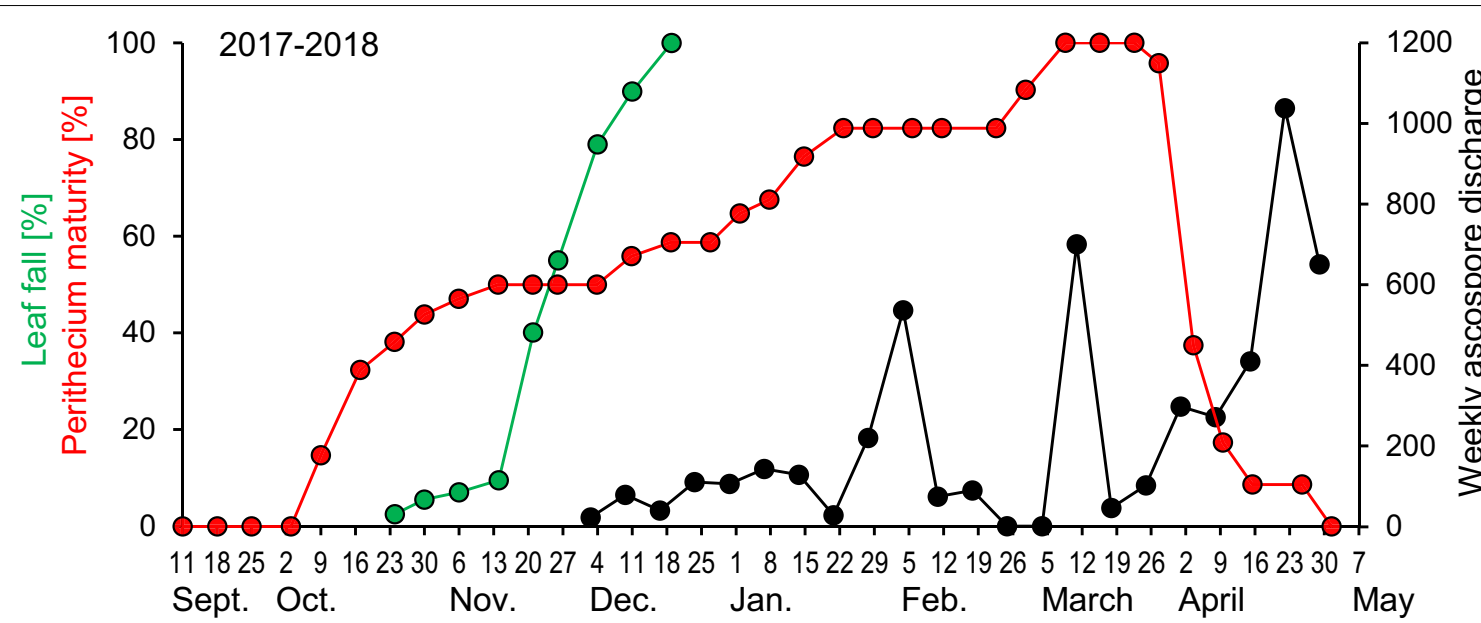

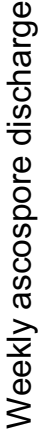

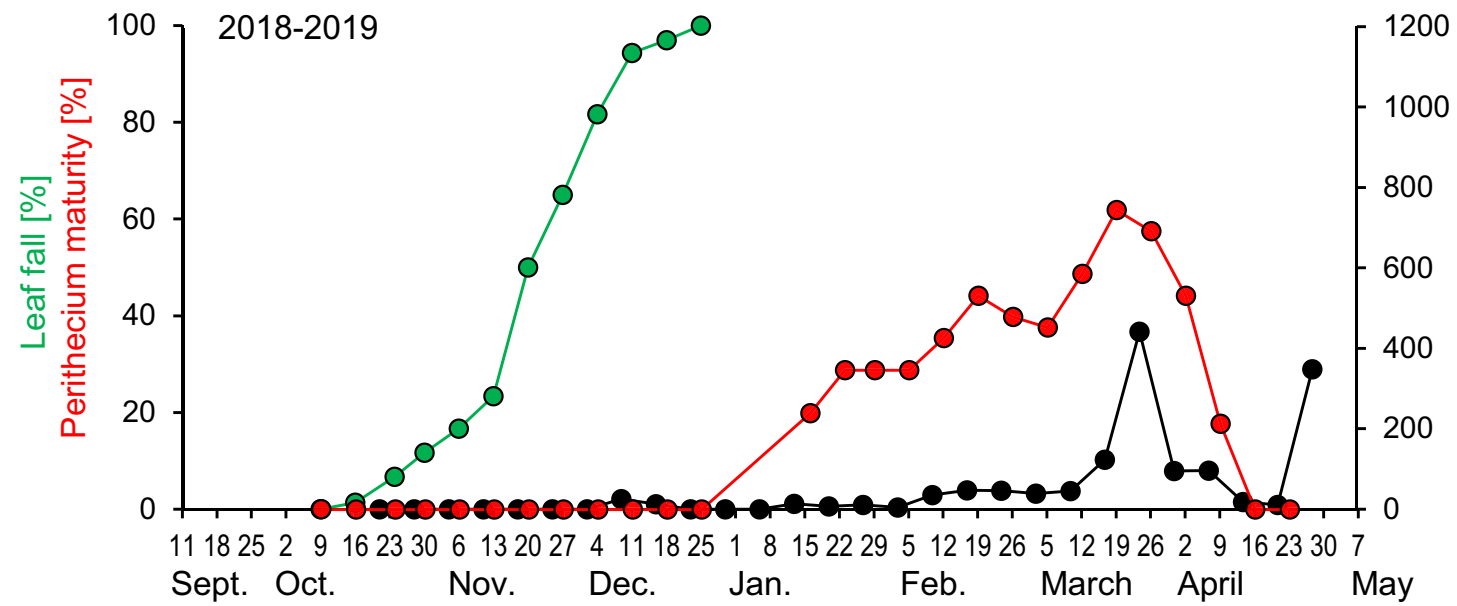

Fig. 3 The timing of ascospore maturity in relation to leaf fall. Leaf fall in canker-susceptible cultivars 'Nicoter'/Kanzi ${ }^{\mathrm{TM}}$ and $^{\prime} \mathrm{Fresco}^{\prime} / \mathrm{Wellant}^{\mathrm{TM}}$ ( $(\mathrm{green})$, percentage of canker lesions with mature perithecia in the orchard (red) and weekly ascospore trappings (black) from detached cankers were recorded at the Esteburg experimental orchard, Northern Germany, in the winter season 2017-2018 following a wet summer, and 2018-2019 following a dry summer

(Saure 1961; Graf 1976) and other regions (Amponsah et al. 2015; Alves and Nunes 2017), whereas they have been credited with a major role in Southwest England (Marsh 1939) and Northern Ireland (Swinburne et al. 1975). Either way, intensive sprays against scab from bud break onwards also have an effect against $N$. ditissima (Cooke 1999). A peak discharge of ascospores in spring would therefore reduce their putative role in the disease cycle (Weber 2014).

A delay in ascospore discharge until early spring contradicts recent results from New Zealand where they are released all year round (Amponsah et al. 2017a), although it is in line with reports from the British Isles (Munson 1939; Swinburne 1971), previous data from Northern Germany being inconclusive (Saure 1974; Wessel 1979).

\section{Aspects of cultivation}

It is a fundamental tenet of plant pathology that the severity of many aerial plant diseases and pests increases with more vigorous vegetative plant growth (Agrios 2005). This is also evidently the case with apple canker. Saure (1963) found that elevated nitrogen fertilisation had a pronounced direct effect on the nitrogen content and growth of trees as well as on the growth of cankers from artificial bark inoculations (Fig. 4). Similarly, root pruning versus additional nitrogen fertilisation resulted in reduced versus enhanced canker growth relative to the unmanipulated control (Saure 1963). This provides experimental support for numerous observations in Northern German apple orchards that the incidence of canker is often reduced rather than enhanced in situations where tree growth is negatively affected by adverse 


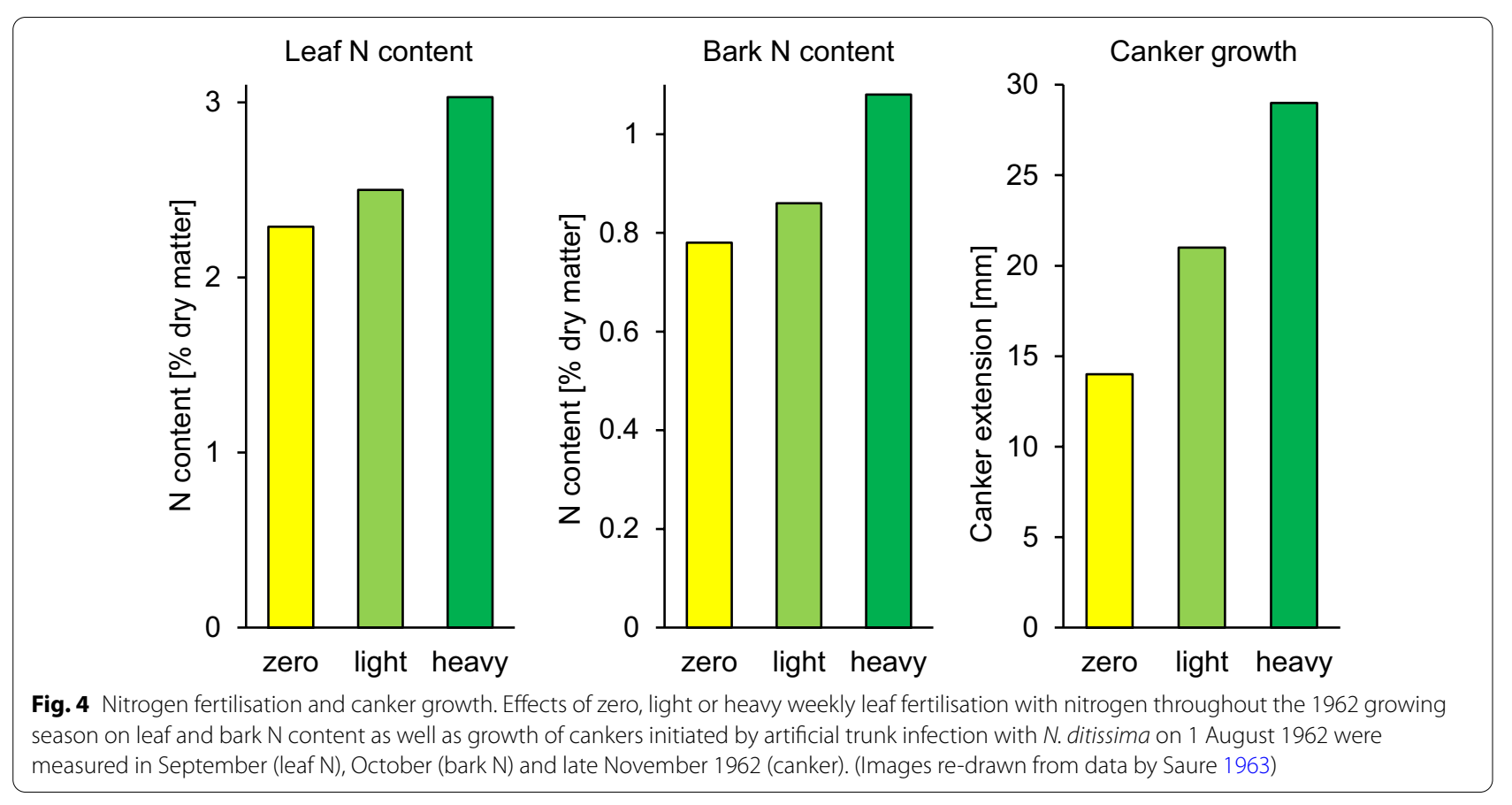

local soil factors (Saure 1961). It remains unclear whether this effect is due to the soil properties themselves (e.g. waterlogging), or to stress caused by them. The age of a plantation is a related factor, actively growing trees ( $<5$ years old) being generally more susceptible to high economic losses to canker than older trees (Saure 1963). In addition, young trees with trunk cankers usually need to be uprooted whereas older trees may survive (Loewel and Saure 1959; Weber and Hahn 2013; see below). The conclusion for practical fruit farmers is that fertilisation should be restricted to a necessary minimum during the first few years of an orchard's lifetime, especially when planting highly canker-susceptible cultivars in exceptionally fertile soils such as the Lower Elbe region. Root pruning, commonly deployed to down-regulate excessive vegetative growth in favour of fruit development, could contribute an additional means to reduce canker. Similarly, prohexadione-calcium is sprayed in the Lower Elbe region to reduce long-shoot growth of trees, and this compound has a known suppressant effect against fireblight (Yoder et al. 1999) as well as apple scab and other diseases (Bazzi et al. 2003). An effect against canker has not been reported, but appears conceivable. Such synergistic effects arising from a more balanced tree growth should be exploited to control canker in the context of modern IPM approaches.

An interesting trial has been reported recently from New Zealand where nitrogen leaf fertilisation with urea sprays after harvest led to a significant increase in artificial canker infections at leaf fall (Dryden et al. 2016).
In this case it is difficult to postulate an effect on plant growth; rather, elevated nitrogen levels seem to have promoted $N$. ditissima in a more direct way, either in terms of nutrition or by bud tissue damage which can result from post-harvest urea applications (Wood and Beresford 2000). Foliar nitrogen fertilisation is widely practised in Northern Europe during the vegetation period as well as after harvest, and critical regional experimentation is required to assess its impact on natural infections by $N$. ditissima and other pathogens.

\section{The importance of healthy nursery plants}

Reports of putative contaminations of nursery trees with $N$. ditissima have a long history. For example, Loewel and Saure (1959) described an extreme case in which $54 \%$ of trees in a 'Cox Orange' orchard had to be uprooted due to canker after the end of the first growing season. However, it was left to McCracken et al. (2003) to provide conclusive molecular biological evidence that many cankers which become visible on young trees in commercial orchards can be traced back to nursery infections. Hence, the full commercial relevance of such nursery contaminations has not been acknowledged until relatively recently (Jansonius et al. 2004).

Putative nursery infections that become visible in production orchards may differ in their appearance, depending on the method of tree production. The most common tree type, currently supplied especially by Dutch and Belgian nurseries across the whole of Northern Europe, is the 'knip tree' in which the scion shoot is headed back 
during winter dormancy, permitting a lateral shoot to grow and produce abundant side branches (feathering) in the second year. The most common canker on such feathered trees is a lateral canker on the main trunk either at branching points (Fig. 5a) or in wounds after defeathering on the lower part of the tree (Fig. 5b). Weber and Hahn (2013) gave an example in which over $25 \%$ of knip trees of the highly susceptible cultivar 'Nicoter' (marketed as $\mathrm{Kanzi}^{\mathrm{TM}}$ ) were affected by trunk canker by August, i.e. within 4 months of their explanting. A large-scale survey in the Lower Elbe region by Zabel (2011) indicated average tree losses of $5 \%$ in 'Nicoter'/Kanzi ${ }^{\text {TM }}$ orchards planted in winter $2008 / 2009$, and $15 \%$ in orchards planted two years previously. Zabel (2011) traced back these differences to variations in nursery contamination in individual production years. In Norway, with a colder climate and shorter growing season the incidence of canker in knip trees is usually much lower in the year of planting than in the year after planting (Børve, unpublished).

Trees without feathers were commonly planted in Norway in the past. On such trees, cankers often emerged at the graft union (Fig. 5c), leading to tree death. Extreme cases of $13 \%$ and $42 \%$ of affected trees within one year after planting were recorded. The average extent of nursery infections from both non-feathered trees and feathered trees in 19 commercial orchards was much lower (Børve et al. 2019). The nursery origin of such infections was evident not only from the conspicuous location of the cankers, but also from the correlation of their incidence with the abundance of cankers on the scion wood mother trees, and from artificial inoculation experiments (Børve et al. 2019).

Sudden death is a third, less common type of canker which has been found in a few orchards in Northern Germany where it killed a high proportion of trees (Weber and Klopp 2006), indicating that individual batches of nursery trees were highly contaminated. Affected trees showed normal growth for about two seasons, only to die of a symptom resembling collar rot but being due to $N$. ditissima girdling the entire trunk at or below the graft union. The outbreak of this infection was so sudden that no obvious callus formation occurred (Fig. 5d). Whilst the decline of individual trees progressed rapidly, the period in which new trees developed symptoms stretched over several years, obliging the farmer repeatedly to replace trees. Especially this third case suggests that $N$. ditissima is capable of surviving prolonged latency periods within the apple tree trunk (McCracken et al. 2003; Amponsah et al. 2017b).
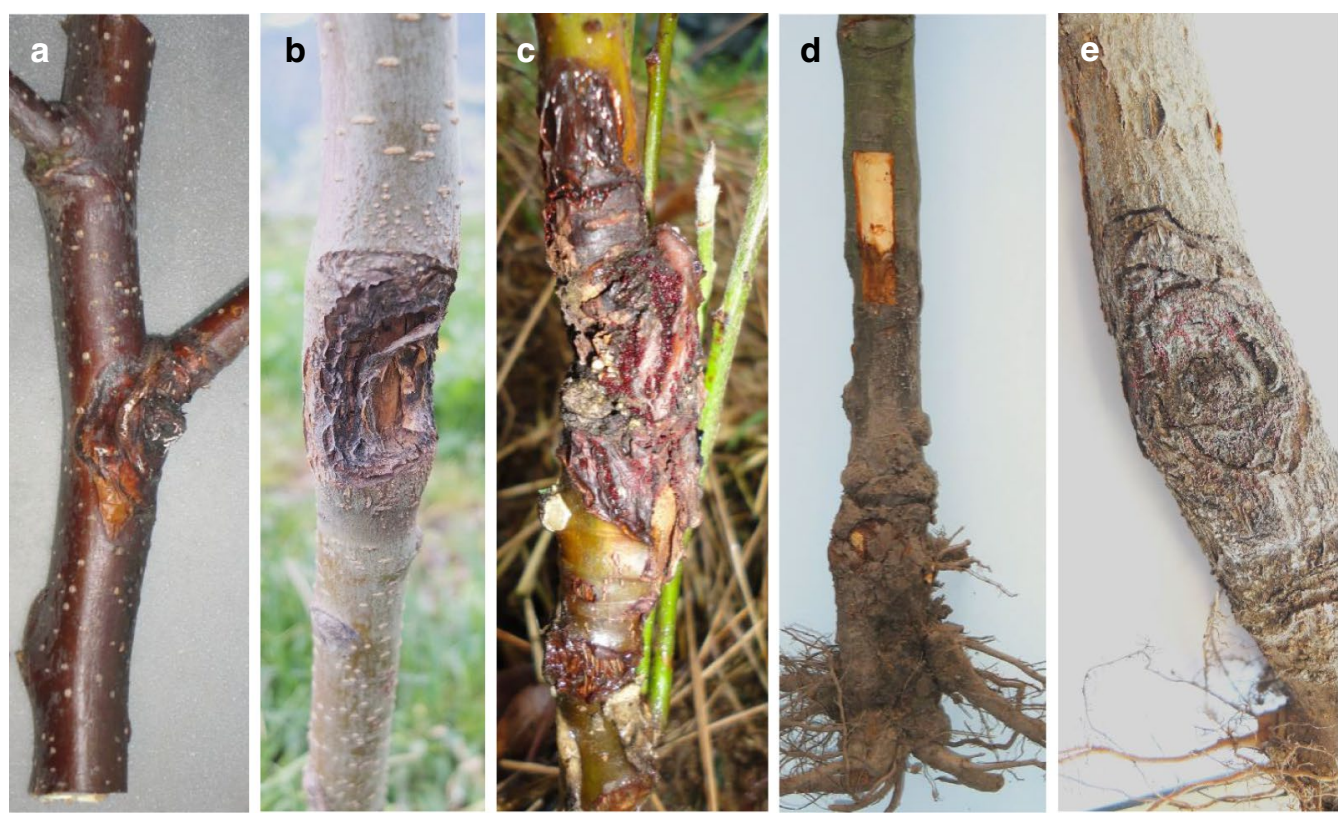

Fig. 5 Nursery tree infections by Neonectria ditissima becoming visible after explanting of infected trees into the production orchard. a Trunk canker on cultivar 'Nicoter'/Kanzi ${ }^{\text {TM }}$ in August 2011, only 4 months after explanting of a nursery tree in Northern Germany. b Trunk canker on 'Santana' at the end of its second growing season in a Norwegian orchard. c Development of canker at the graft union of cultivar 'Discovery' with rootstock M9, photographed in November 2014 at the end of the first growing season in an orchard in Western Norway. Perithecia have already formed, and adventitious shoots have been emitted by the rootstock. $\mathbf{d}$ Sudden emergence of canker enclosing the entire trunk near the graft union of cultivar 'Topaz' on rootstock M9 about three years after explanting. A strip of the bark has been removed to reveal the infection front. e Canker with perithecia on rootstock B9 a year after planting in Norway 
Lateral cankers on rootstocks (Fig. 5e) and lower parts of the trunk are easily observed when trees show symptoms of decline. In Norway, an incidence of up to $6 \%$ of trees with such cankers was observed a year after planting in 2019 (Børve, unpublished data). The rootstocks might become infected by $N$. ditissima during propagation, and rootstock B9 seems to be more prone to infection than the most commonly used rootstock M9 (Børve et al. 2018).

Infections of nursery trees which do not become visible as cankers until the second growing season or beyond are particularly troublesome for the fruit farmer because the nursery connection is often overlooked by regional consultants, or, if diagnosed correctly, it becomes difficult to make a convincing case to support claims for compensation from nurseries after such a long time. In addition, replacing trees after two years or more introduces heterogeneous tree sizes and makes orchard management more difficult.

\section{Cultivar differences and resistance breeding}

There are obvious differences in the susceptibility of apple cultivars to $N$. ditissima (Weber 2014; Scheper et al. 2018). However, there is no known monogenetic resistance to canker in apple (Garkava-Gustavsson et al. 2013; Ghasemkhani et al. 2015; Gómez-Cortecero et al. 2016), i.e. cultivar differences are probably based on the additive effects of several minor genes. The underlying molecular mechanisms of host-pathogen recognition and of host defence remain unclear as yet but are beginning to be unravelled (Bus et al. 2019). Genes might be constitutively expressed as a basal defence, or they might be involved in an induced response (Gómez-Cortecero et al. 2016). Vigorous callus formation is regarded as a visible sign of resistance (Crowdy 1952; Kennel 1963), whereas the formation of large cankers, high sporulation of $N$. ditissima on these cankers, or the growth of the fungus into woody tissues beyond the boundaries of the canker are viewed as signs of high susceptibility of a cultivar (Gómez-Cortecero et al. 2016). These distinctions are in line with practical observations from commercial orchards in Northern Germany where e.g. 'Nicoter'/ $\mathrm{Kanzi}^{\mathrm{TM}}$ meets all specifications of a highly susceptible cultivar (Weber and Hahn 2013; Weber 2014).

Because the incidence of canker may be modulated by the extent of nursery contamination and by local factors such as soil, fertilisation or climate, there are regional differences in the perception of canker susceptibility of certain cultivars. For example, 'Braeburn' was once considered to be more resistant than 'Elstar' as a result of trials in several commercial orchards in the Lower Elbe region (Palm 2009; Palm et al. 2011), but a limitation of these studies was that trees had been supplied by different nurseries. Subsequent observations in the Lower Elbe region (Weber 2014) and comparative studies elsewhere (Scheper et al. 2018) have shown 'Braeburn' to be moderately susceptible. Apart from the uncertainties of nursery infections, cultivar assessments are also limited by methodology, e.g. high-throughput approaches such as artificial inoculations of detached shoots yielding substantially different rankings of cultivar susceptibility than potted-tree assays (Ghasemkhani et al. 2015; Gómez-Cortecero et al. 2016; Scheper et al. 2018).

In order to obtain a more reliable assessment relevant to commercial practice, we have initiated a trial in which several Northern European standard cultivars were obtained from the same nursery and planted side-by-side in two Norwegian and two Northern German orchards differing in local climate. This trial is still ongoing, but it is already beginning to reveal interesting results in that relative cultivar susceptibility can be influenced by location (Weber and Børve, in preparation). A plausible explanation for such results lies in cultivar-specific phenological traits which might make harvest dates or leaf fall periods fall into times of higher or lower canker infection pressure in a given autumn season.

Even though there is no cultivar with total resistance to $N$. ditissima as yet, breeding for (partial) resistance is still a promising undertaking because (i) many currently grown cultivars are highly susceptible, as we have seen, and (ii) the population structure of $N$. ditissima appears to be relatively uniform in different regions of the world and on different hosts (Gómez-Cortecero et al. 2016). Thus, a cultivar harbouring resistance would have a worldwide commercial potential at least from a plant pathologist's point of view.

During the final stages of screening prior to their commercial introduction, new cultivars are currently tested mainly for production-related parameters (growth, yield, storage behaviour) and for market demands (taste, fruit quality) but not for susceptibility to key plant diseases in different production regions. This lack of cross-talk between breeders and plant pathologists probably facilitated the release of 'Nicoter'/Kanzi ${ }^{\mathrm{TM}}$ and other highly canker-susceptible cultivars to commercial production. Structural changes at applied fruit research institutions leading to multidisciplinary approaches to cultivar testing are needed to avoid similar cases in future.

\section{Pruning and painting}

It is apparent to all fruit farmers that cankers are unevenly distributed within their orchards (Campbell et al. 2016). This is because individual trees in which one or a few older cankers have been overlooked during pruning in one year will go on to develop numerous new cankers in the following season (Saure 1972; Weber and 
Hahn 2013). Thus, the central role of conidia in spreading infections within trees is the practical justification for canker pruning as an essential component of IPM (Fig. 6). Similarly, the incidence of blossom-end rot of apple fruit caused by conidial infections at flowering often correlates with the presence of cankers on individual trees (Weber and Dralle 2013).

It follows from the infection biology of $N$. ditissima that canker lesions should be removed from the trees before they can produce the first conidia. Because cankers may develop faster and sporulate earlier and more profusely on highly susceptible cultivars (see above), these cultivars must be pruned more rigorously and more frequently. Young orchards must be pruned more carefully than older ones because young trees are more susceptible (see above). Suitable time-points are winter (easy visibility of cankers), pre-flowering (prevention of flower infections causing blossom-end fruit rot) and repeatedly after flowering until the end of June (mass emergence of cankers from fruit and leaf scar infections initiated in the previous autumn). However, as the very high disease levels in the untreated controls of our fungicide trials demonstrate (see below), even the most assiduous pruning will not be

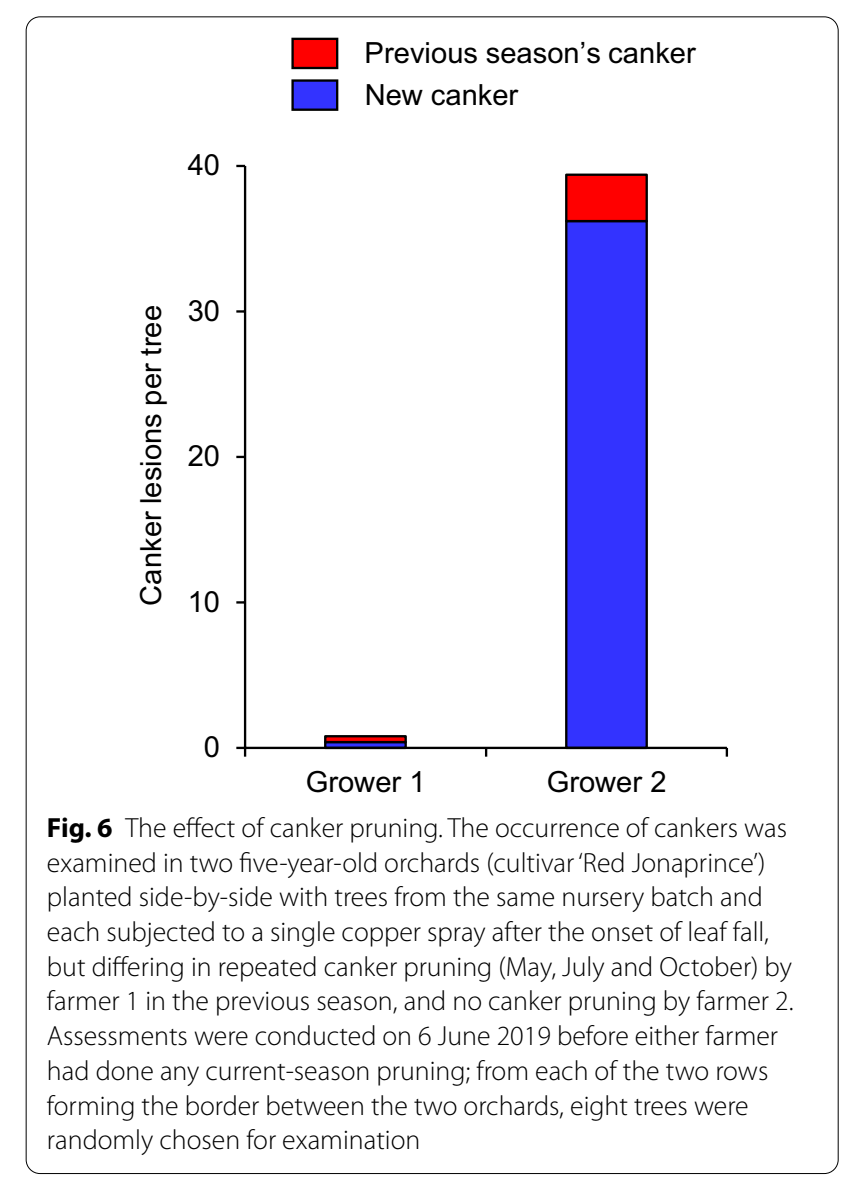

sufficient as a sole canker control measure with highly susceptible cultivars. Pruning and chemical control are two integral components of IPM (Saure 1974).

In order to reduce labour costs, canker pruning can be combined with powdery mildew pruning (Palm and Kruse 2010) or with general summer or winter pruning measures. Although cankers can continue to release ascospores from dead wood on the orchard floor, the practical relevance of this is unclear (Wessel 1979), and in current Northern German practice only larger branches and trunks are removed from the orchard at pruning. This is especially important for firewood piles from orchard clearings.

The period of high susceptibility of fresh pruning wounds to $N$. ditissima infections lasts for about one week during the vegetation period, and up to 3 weeks in winter (Krähmer 1980; Xu et al. 1998). Therefore, pruning should be conducted preferably during periods of dry weather. Naturally, this is not always possible, raising the issue of wound protection. An obvious way to protect fresh pruning wounds is to synchronise pruning activities with a fungicide spray. However, trials with captan (Walter et al. 2019) have provided evidence that fungicides may not be able to protect large wounds with the same efficacy as small leaf scars in autumn. Further, copperbased products cannot be sprayed at concentrations relevant to canker control from shortly after bud break until harvest because of strong phytotoxic damage to the fruit surface (Weber and Kruse 2018).

A different approach lies in painting large individual wounds. Variable opinions exist between different fruitgrowing regions concerning the efficacy of such a measure. Painting cankers without prior pruning has proven ineffective at least in Northern Germany even with the most effective canker fungicides such as phenyl mercuric nitrate which was available in the 1960s, or with the curative methyl benzimidazole carbamate (MBC) fungicide thiophanate-methyl (Saure 1962; Graf 1976). Similar trials in New Zealand with tebuconazole, MBC fungicides, copper oxychloride or biological control agents gave equally disappointing results (Walter et al. 2017b). The painting of fresh pruning wounds with fungicides such as copper in mineral oil was proposed as a measure against new $N$. ditissima infections and also to prevent resurgent infections from any residual canker tissue left behind by incomplete pruning (Graf 1976). MBC fungicides, sometimes in mixture with a triazole, are also effective (Graf 1976; Scheper et al. 2008, 2016). The dressing of wounds with different pastes may promote wound healing under certain circumstances as compared to untreated control wounds, but the effort was rarely worth the money and time in relevant trials (Saure 1962). Following these and other trials, pruning wounds are commonly left 
untreated in Northern Germany (Saure 1974). No fungicide-containing wound dressing is currently registered in Germany or Norway.

The painting of wounds is recommended in different countries such as England (Cross et al. 2020), Brazil (Alves and Czermainski 2015), and New Zealand (Walter et al. 2016). In New Zealand paints with the MBC fungicide carbendazim have been specified (Scheper et al. 2008). Tebuconazole is an alternative fungicide registered in in many countries in this indication.

An additional contribution to preventing the wound entry of $N$. ditissima is to avoid unnecessary wounds. In Norway, for example, the most common type of canker after a few years in the orchard is located at points where wires and poles of the support system are rubbing the trees, causing bark injuries (Børve, unpublished data). To a lesser extent, this has been observed also in Northern Germany (Weber and Hahn 2013). Care during tree education is warranted.

\section{Chemical control options}

Hardly any aspect of apple canker research is as controversial, and has such strong regional flavours, as chemical control. This may be due to uncertainties about the relevance of different types of wound, the timing of inoculum availability, and differences in national fungicide registration. In addition, much variation has arisen from different experimental approaches, e.g. artificial versus natural infection of artificial versus natural wounds. This is highly relevant if artificial wounds are all of the same age whereas natural wounds such as leaf scars arise over a long time period, thus posing different challenges to the durability of a fungicide spray. In general terms, coppercontaining fungicides are preferred wherever permitted by national registration because the low solubility of certain copper salts provides a depot effect by which bioactive $\mathrm{Cu}^{2+}$ ions are released at each rainfall, and distributed through the film of surface water (Saure 1965). This ensures a high rainfastness of over $100 \mathrm{~mm}$, which is crucial in order to reduce the number of orchard passages to a minimum at a time of year when access with heavy machinery may be impaired by waterlogging. For historic reasons, copper oxychloride has been the favourite copper compound against canker in many countries (Graf 1985; Cooke et al. 1993; Walter et al. 2015b).

Protectant fungicides such as captan or systemic compounds such as methyl benzimidazole carbamates (MBC) have been favoured by advisors in some countries such as the Netherlands (van der Scheer 1974; Westerlaken and van Dijke 1987; de Jong and van der Steeg 2012), based partly on trial results, partly out of necessity as substitutes for copper fungicides where the latter are not registered. However, the efficacy of captan against
$N$. ditissima may be limited especially at a high infection pressure on large wounds (Westerlaken and van Dijke 1987; Walter et al. 2019). A large proportion of captan is washed off from leaf surfaces by the first rain event, a smaller proportion being retained until $>25 \mathrm{~mm}$ rainfall has occurred (Smith and MacHardy 1984; Xu et al. 2008). This may temporarily lead to a redistribution of captan from leaves to leaf scars especially in the presence of spreader adjuvants. Leaf scars and other rough bark surfaces seem to offer an improved retention of captan as compared to leaf surfaces (Gaskin et al. 2014). In the case of MBC fungicides, a reduced sensitivity of $N$. ditissima has been reported both from Northern Germany (Weber and Palm 2010) and New Zealand (Walter et al. 2014), possibly indicating a shift towards resistance. This correlates with a low or unreliable performance of MBC fungicides in Northern German field trials (Palm 2009) and elsewhere (Cooke et al. 1993), at least when used as autumn sprays.

\section{Northern German field trials}

Although field trials based on natural infections need to be conducted on a larger scale than experiments involving artificial inoculation, they have the distinct advantage of providing us with data generated under the same conditions as those which farmers experience in their orchards. In Northern Germany, such field trials have been carried out for several decades in a standardised manner, in which commercial orchards were chosen as trial sites, sprays were applied in two successive autumn seasons, and cankers were scored, pruned and removed from the orchard in all variants including the unsprayed control during each full vegetation period following an autumnal spray sequence.

An example of numerous such large-scale trials is given in Fig. 7 (excerpted from Palm 2009). In this case the highly susceptible cultivar 'Civni' (marketed as Rubens ${ }^{\mathrm{TM}}$ ) was chosen, which characteristically develops more cankers on the trunk than on side branches or twigs. At the beginning of the trial, the vigorously growing trees were at the end of their second growing season. Each treatment of the trial was repeated four-fold, each repeat plot comprising three rows in width and 20 trees in length. For evaluation, 13-15 canker-free trees per repeat were chosen before the beginning of the experiment. At the same time, all cankers were pruned off from all trees in the orchard, and trees with trunk canker were uprooted and removed. Three sprays were conducted in each of two successive spraying seasons, applying the fungicides in $500 \mathrm{l}$ water ha ${ }^{-1} \mathrm{~m}^{-1}$ canopy height $\left(=1250-1500 \mathrm{l} \mathrm{ha}^{-1}\right)$ with a hand-held spray gun. The intended dates-25-50\% leaf fall, end of leaf fall, and winter dormancy-could not be adhered to because of difficult weather conditions 

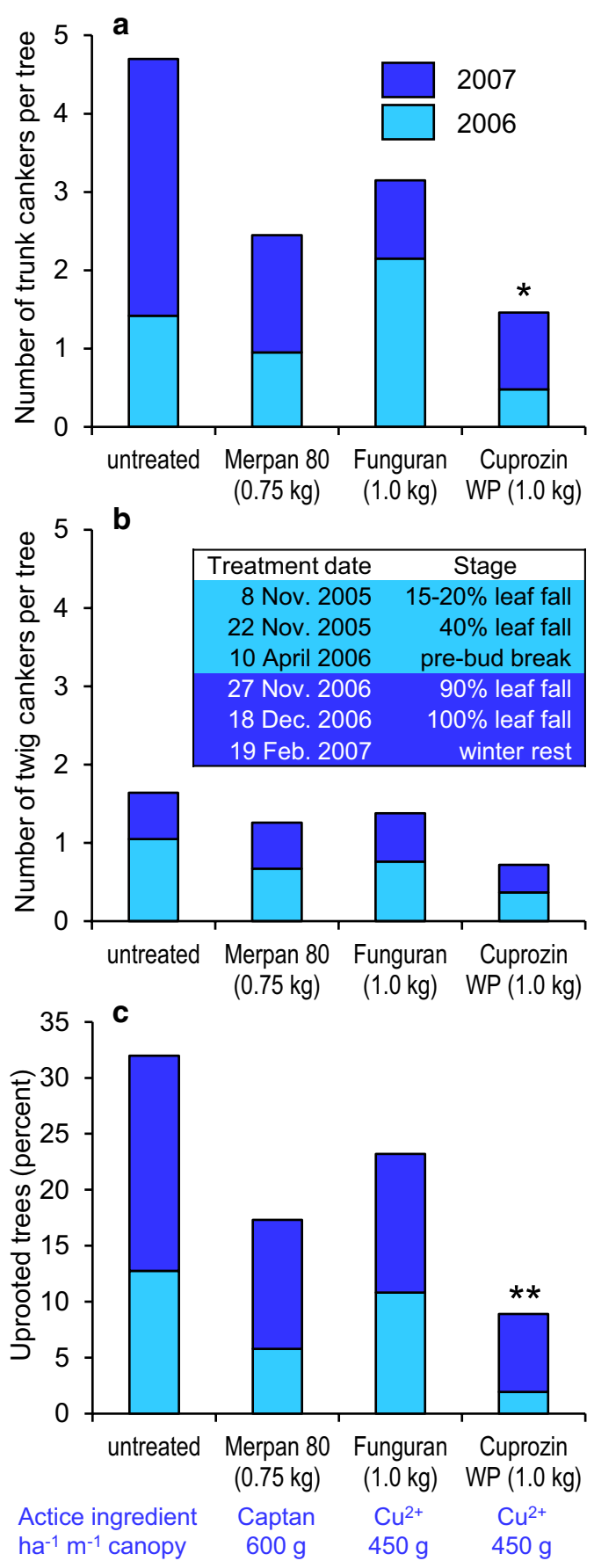

(see Fig. 7). With the exception of our canker sprays, the entire orchard was managed uniformly by the fruit farmer according to regional IPM practice throughout the trial period, including sprays against scab (dithianone, captan, dodine), powdery mildew (trifloxystrobin and triazoles) and storage rots (captan and trifloxystrobin). The results, expressed as cumulative numbers of trunk canker per tree (Fig. 7a), showed a high and significant
Fig. 7 Efficacy of copper and captan fungicides against canker. Copper hydroxide (Cuprozin WP), copper oxychloride (Funguran) and captan (Merpan 80 WDG) treatments after harvest were evaluated in terms of trunk canker (a), twig canker (b) and uprooted trees due to severe trunk canker (c) in a young 'Civni'/Rubens ${ }^{\mathrm{TM}}$ plantation which was at the end of its second season at the beginning of the trial. Sprays were made at the dosages ( $\mathrm{ha}^{-1} \mathrm{~m}^{-1}$ canopy) and times indicated. The canopy height was $2.5 \mathrm{~m}$ in the first spraying season, and $3.0 \mathrm{~m}$ in the second season. Disease incidence assessments with removal of all cankers were made in June 2006, November 2006 and November 2007. Treatments labelled with asterisks were significantly different $\left({ }^{*} P<0.05 ;{ }^{* *} P<0.01\right)$ from the untreated but canker-pruned control according to Dunnett Contrast post-hoc analysis of contrast matrices using the 'multcomp' package (Hothorn et al. 2008) in the R software, version 4.0.2 (R Core Team 2020). (Re-drawn from Palm 2009, with permission)

$(P<0.05)$ efficacy of copper hydroxide (Cuprozin WP), but no significant difference between the untreated control and captan (Merpan 80 WDG) or copper oxychloride (Funguran) treatments. In twig infections, no significant difference between any of the treatments was observed (Fig. 7b). Trunk canker was so severe on 'Civni'/Rubens ${ }^{\mathrm{TM}}$ that over $30 \%$ of the unsprayed control trees had to be replaced at the end of the trial whereas copper hydroxide significantly $(P<0.01)$ reduced tree losses to $<10 \%$, the other fungicides having no significant reducing effect (Fig. 7c). This trial took place on a highly canker-prone site, under adverse weather conditions and with suboptimal spray dates which placed extreme demands on the fungicides under trial. Nonetheless, the efficacy of copper hydroxide was in the order of $50-75 \%$, which is comparable to numerous other trials (Palm 2009; Palm and Kruse 2012; Weber and Kruse, in preparation).

A more recent fungicide trial with the equally highly susceptible cultivar 'Nicoter'/Kanzi ${ }^{\mathrm{TM}}$ is summarised in Fig. 8 (excerpted from Weber et al. 2019). 'Nicoter'/ Kanzi $^{\text {TM }}$ differs from 'Civni'/Rubens ${ }^{\text {TM }}$ in that infections from within the orchard become mainly visible on twigs. This trial was set up in autumn 2014 in a commercial orchard that had been planted in spring 2013. Three successive sprays from leaf fall through to winter dormancy were made in two successive spraying seasons in autumn/ winter 2014 and 2015. As before, there were deviations from the customary application dates (see Fig. 8). The copper oxide-containing fungicide Nordox 75 WG (750 g $\mathrm{Cu}^{2+} \mathrm{kg}^{-1}$ ) was applied at $600 \mathrm{~g} \mathrm{ha}^{-1} \mathrm{~m}^{-1}$ canopy height, corresponding in $\mathrm{Cu}^{2+}$ dosage to $1 \mathrm{~kg} \mathrm{ha}^{-1} \mathrm{~m}^{-1}$ of the long-term experimental copper hydroxide standard Cuprozin WP (450 $\left.\mathrm{g} \mathrm{Cu}^{2+} \mathrm{kg}^{-1}\right)$. In addition, new fungicides containing reduced amounts of copper hydroxide were tested in this trial. Fungicides were applied in $250 \mathrm{l}$ water ha $\mathrm{h}^{-1} \mathrm{~m}^{-1}$ canopy height using a standard fruit orchard sprayer. The canopy height was $2.0 \mathrm{~m}$ in autumn 


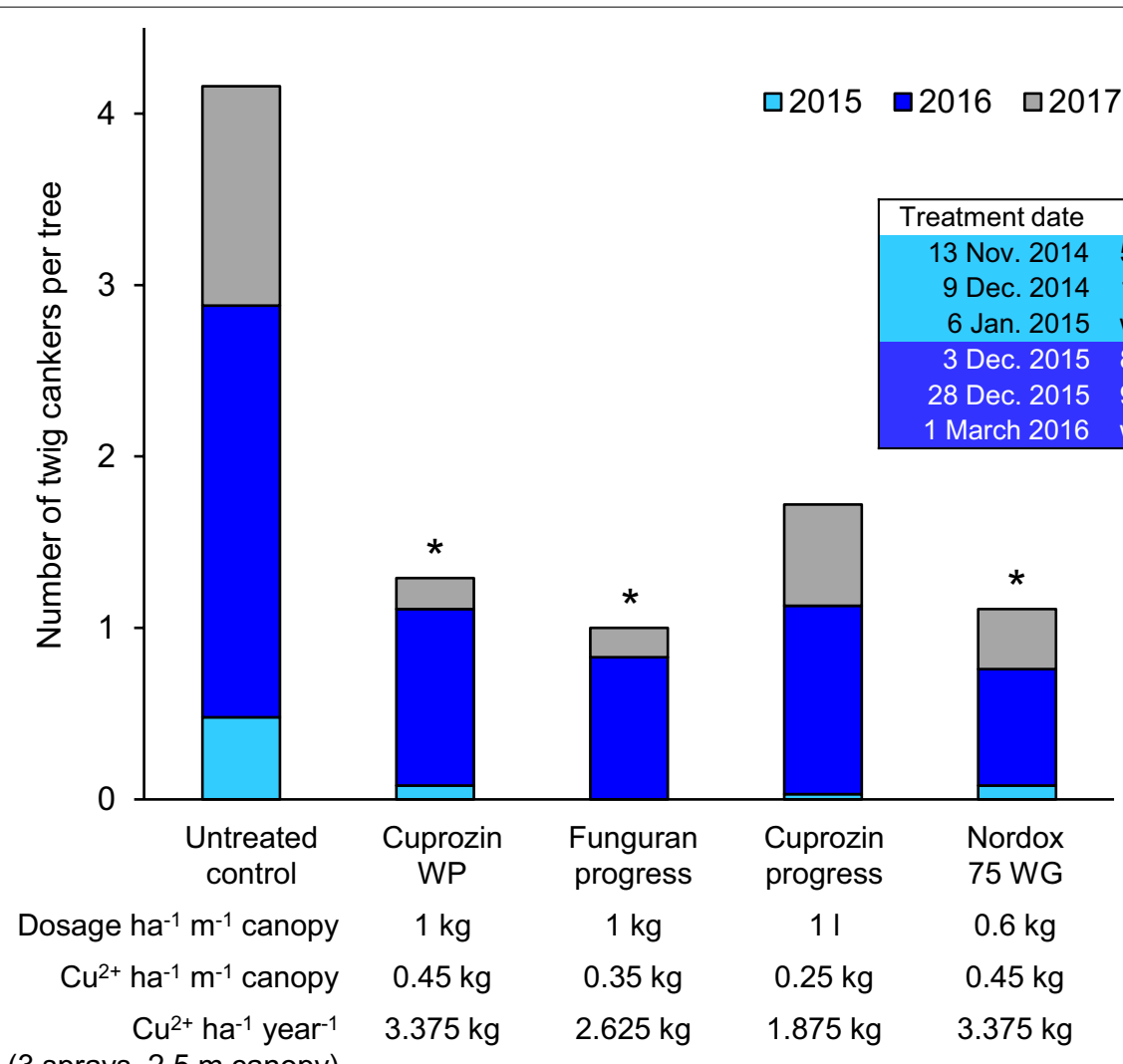

(3 sprays, 2.5 m canopy)

Fig. 8 Efficacy of sprays with different copper dosages against canker. Autumn treatments with different copper hydroxide formulations (Cuprozin WP, Funguran progress and Cuprozin progress) and copper oxide (Nordox 75 WG) were evaluated in a young 'Nicoter'/Kanzi ${ }^{\text {TM }}$ plantation which was at the end of its second year at the beginning of the trial. Sprays were made at the dosage $\left(\mathrm{ha}^{-1} \mathrm{~m}^{-1}\right.$ canopy) and dates indicated. The canopy height was $2.0 \mathrm{~m}$ in the first spraying season, and $2.5 \mathrm{~m}$ in the second season. The development of canker on twigs was evaluated for the two seasons succeeding annual autumn sprays, and for the 2017 season following a standard treatment of all variants with three Funguran progress sprays by the farmer. Disease incidence assessments with removal of all cankers were made 5-7 times throughout each season. Treatments labelled with asterisks were significantly different $(* P 0.05)$ from the untreated but pruned control, as described in the legend to Fig. 7. (Re-drawn from Weber et al. 2019, with permission)

2014, and $2.5 \mathrm{~m} 1$ year later. Each treatment of the trial was repeated fourfold, each repeat plot comprising 5 rows in width and 23 trees in length. During the vegetation period following the winter sprays, canker pruning was conducted across the entire trial at monthly intervals from February or March through to July and then again in October. In each repeat, 10 trees were chosen at the beginning of the experiment to document the number of removed cankers. Disease incidence was expressed as the cumulative number of cankers on the twigs of each tree.

The incidence of twig cankers per tree was significantly $(P<0.05)$ lower on trees treated with the three highest amounts of copper (Fig. 8) relative to the control, which was not treated by these canker sprays but subjected to the same repeated canker pruning and standard fungicide treatments against scab, powdery mildew and storage rots (see above) as all other variants. Further, the effects of copper treatments made in autumn 2014 and autumn 2015 were still observed even in the 2017 season, following a uniform treatment of the entire orchard with copper hydroxide in autumn 2016 by the fruit farmer after the end of our experiment.

Results from both trials demonstrate that Cuprozin WP (copper hydroxide) and Nordox 75 WG (copper oxide) are equally effective in canker control, and more effective than copper oxychloride. This confirms previous Northern German reports for copper hydroxide versus copper oxychloride at identical $\mathrm{Cu}^{2+}$ rates per acreage (Graf 1985; Palm 2009; see Fig. 7), but contradicts results obtained by Walter et al. (2015b) in artificial inoculation trials in New Zealand, and by Cooke et al. (1993) and Cooke (1999) in Northern Ireland.

The comparable efficacies of Cuprozin WP and Funguran progress indicate that changes in the formulation of copper hydroxide offer opportunities to reduce the absolute amount of $\mathrm{Cu}^{2+}$ that has to be applied per unit 
acreage to give acceptable canker control. This is highly relevant because in Germany and many other countries there is a current limit of $3 \mathrm{~kg} \mathrm{Cu}^{2+} \mathrm{ha}^{-1}$ year $^{-1}$. Three sprays at a rate of $1 \mathrm{~kg}$ Cupozin WP ha ${ }^{-1} \mathrm{~m}^{-1}$ canopy with trees of $2.5 \mathrm{~m}$ canopies would exceed that limit $\left(3.375 \mathrm{~kg} \mathrm{Cu}^{2+} \mathrm{ha}^{-1}\right.$ year $\left.^{-1}\right)$ whereas three sprays with the equally effective Funguran progress $\left(2.625 \mathrm{~kg} \mathrm{Cu}^{2+}\right.$ ha $^{-1}$ year $^{-1}$ ) would meet current limits.

\section{Infection biology of $\boldsymbol{N}$. ditissima in commercial orchards}

It should be borne in mind that the above fungicide trials were conducted in commercial orchards managed according to standard IPM from bud break until harvest. The high efficacy of post-harvest sprays with copper against canker in such commercial orchards in Northern Germany indicates that most of the relevant infections must have been initiated in autumn when no collateral protection by other fungicide sprays was available. This ties in with the emergence of cankers in such orchards from pre-flowering until mid-summer mainly on fruit spurs and leaf scars dating back to the previous autumn. Pruning wounds, commonly initiated by pruning measures from late winter until bud break in Northern Germany, rarely develop cankers in regional practice even though they are difficult to protect by fungicide sprays (see above). Likewise, natural wounds arising from bud break onwards are rarely infected despite the occurrence of peak ascospore releases at that time, probably because they are controlled by scab sprays with dodine and dithanone, which are known to be effective also against $N$. ditissima (Cooke 1999). Therefore, our results support the view that ascospores do not play a major role in the disease in current Northern German apple production.

Trees that had been left untreated in autumn in the second trial described here (Fig. 8) still showed an elevated rate of new canker development in the second season after the end of sprays, i.e. the first season following repeated uniform autumn sprays of the entire orchard by the fruit farmer. This confirms practical experiences among consultants and orchardists that it requires several years of intensified spray and pruning efforts to mitigate the effects of a heavy canker outbreak. We are unsure about the biological basis of such long-term follow-on effects. As our surveys indicate, ascospores may not be formed in time for leaf scar and especially fruit scar infections in autumn, leaving conidia as the main inoculum. Since these spread mainly within trees, their source should be eliminated by pruning especially in young trees where cankers are prominently visible. Could conidial inoculum be produced elsewhere on the tree? We have occasionally found conidia on fruit mummies, i.e. the shrivelled dead remains of fruit aborted during the season (Weber 2012). These would not be removed during canker pruning. We are currently examining whether there is a correlation between the incidence of canker and the colonisation of fruit mummies by $N$. ditissima. A different explanation assumes a long-term latency of canker infections even on susceptible cultivars, in which a large proportion of infections established in the autumn of one year might not become visible as cankers until the spring of the year after next. The argument against this is that most cankers in commercial orchards appear on recent rather than 1-year-old leaf and fruit scars, and this was also the case in the trial summarised in Fig. 8.

\section{Conclusions: current canker control}

The control of canker in Northern German and Norwegian IPM orchards is a finely tuned system which is currently based on specific canker sprays at leaf fall, general scab sprays throughout the season, canker pruning in winter as well as during the growing season, and cultivation methods aiming to achieve a balanced tree growth.

Chemical control remains a cornerstone of canker management, and serious problems would arise e.g. from the end of registration of copper fungicides. As discussed above, captan is no equivalent substitute in periods of prolonged rainfall in autumn, although it is often used as a first spray after the last fruit picking and/or at the beginning of leaf fall in Northern Germany in orchards suffering from high scab and/or canker infestation, and in wet weather. The application dates for captan until incipient leaf fall follow the recommendations for scab prevention. If fungicides with a reduced rainfastness such as captan have to be used during leaf fall, dedicated canker forecasting models can be helpful to pinpoint times of fungicide applications (Saville and Olivieri 2019). Unfortunately, their practical use is compromised by conditions prohibiting repeated access to orchards by muddy soils. These are, of course, the very same conditions of high rainfall in which fungicides are essential for canker control. Therefore, three sprays typically timed to the beginning, middle and end of leaf fall are still recommended in Northern Germany as well as in many other countries such as Brazil (Valdebenito-Sanhueza et al. 2012) or England (Cross et al. 2020), whereas sprays at weekly intervals during leaf fall are recommended in New Zealand (Walter et al. 2015b). Copper sprays may be used at one or more of these dates, the other products being captan, triazoles or thiophanate-methyl (the latter two not being registered in Northern Germany for canker control). Our ongoing work includes efforts at further reducing the input of $\mathrm{Cu}^{2+}$ by reducing the dosage or omitting any one of the three Northern German spray dates (first half of leaf fall, end of leaf fall, winter). For less susceptible cultivars, Northern German fruit farmers generally reduce 
the number of autumn sprays from three to one or two. Modifications of the canker spray schedules and dates may have to be considered in adaptation to the rapidly accelerating effects of global climate change which will bring milder, wetter winter seasons to Northern Europe (Christensen et al. 2011).

At least one canker pruning measure during the winter and one additional measure during the vegetation period are standard practice in all Northern German orchards under IPM. An upscaling of canker pruning to 3-5 measures during the vegetation period is recommended for highly susceptible cultivars and/or strongly canker-affected orchards. The first such measure should be conducted just ahead of flowering in order to reduce fruit infections leading to blossom-end rot (Weber and Dralle 2013).

Nitrogen fertilisation should be restricted, depending on soil conditions (Klopp 2020). In orchards with humusrich soils $(>4 \%)$ and vigorously growing trees, no $\mathrm{N}$ fertilisation is necessary. On loamy soils in the core area of the Lower Elbe region, a single dose of $<50 \mathrm{~kg} \mathrm{~N} \mathrm{ha}^{-1}$ should be applied in early spring, whereas on lighter soils with a reduced ability to retain $\mathrm{N}$ a total amount of $60-90 \mathrm{~kg} \mathrm{~N} \mathrm{ha}^{-1}$ should be given in up to three deliveries from bud break until June, depending on $\mathrm{N}$ washout due to precipitation. As discussed before, root pruning and prohexadione calcium are additional ways to reduce vegetative growth.

\section{Outlook: future options}

Restrictions in accessing orchards with the current spray technology of heavy tractor-pulled equipment during wet autumn seasons may act as a stimulus for the introduction of advanced technology into European orchards. However, in order to achieve good fungicide efficacies a large volume of water is needed, e.g. $1000 \mathrm{l} \mathrm{ha}^{-1}$ in New Zealand with captan (Walter et al. 2019) or in Northern Germany with copper fungicides (see above). This is a major obstacle to using lighter equipment. An overview of future technological developments has been provided by Zhang et al. (2019). There are synergisms between technical advances and forecasting models: should it become possible to apply sprays independently of soil conditions, forecasting models would assume a greater importance and the use of copper fungicides could be further reduced.

Classical topical applications of biological control agents do show some effect under controlled conditions (Saville and Olivieri 2019) but are unlikely to give the required level of control in practice (Walter et al. 2017a). An interesting idea was mooted by Saville and Olivieri (2019) who reviewed evidence of endophytic fungi capable of mitigating $N$. ditissima infections. In particular, they suggested that the extent of colonisation of apple cultivars by such fungi might partly explain differences in cultivar susceptibility to canker. If such fungi could be used to inoculate apple trees, a more stable form of biological control sheltered from weather extremes and fungicide effects might be possible. Unfortunately, endophytes often hold more promise than they fulfil, and such research is still at a preliminary stage.

The planting of canker-resistant cultivars is an obvious goal in the context of IPM. However, in practice the susceptibility to diseases is only one of many factors to be considered by a fruit farmer choosing his portfolio of cultivars. Market demands tend to dominate over IPM ideas, as indicated by the worldwide promotion of an extremely susceptible cultivar such as 'Nicoter'/Kanzi ${ }^{\mathrm{TM}}$ and its commercial success even in canker-prone areas (Zabel 2011; Weber and Hahn 2013). Along a similar logic, cultivars susceptible to apple scab such as 'Braeburn, 'Elstar' or 'Jonagold' continue to be grown by organic farmers in Northern Germany at the price of a high frequency of sprays with lime-sulphur, wettable sulphur or reduced amounts of copper (Kienzle 2018) despite the availability of excellent scab-resistant cultivars, simply because customers demand organically produced fruit of their favourite varieties. Therefore, even if a canker-resistant cultivar was available, it would have to jump the high hurdle of market placement and customer acceptability.

It may take years to bring canker back under control in a severely affected orchard. This is particularly true of young orchards. More emphasis must be placed on producing healthy trees. More rigorous quality control systems are desirable, although the key problem here is the difficulty in reliably detecting latent $N$. ditissima infections in individual nursery trees at the point of delivery to the farmer (Saville and Olivieri 2019). It remains to be seen whether the accelerated development of canker symptoms in randomly selected nursery trees incubated at higher temperatures (Wenneker et al. 2017) is practicable at the level of individual farms. Preferably, this should be conducted by the nurseries for trees randomly sampled from each plot as part of an improved quality control scheme. Meanwhile, the continued use of copper fungicides should be permitted by restrictive countries at least in their nurseries because considerable savings of fungicide sprays in production orchards would be possible if farmers could rely on healthy nursery trees.

\section{Acknowledgements}

Alina Appel, Katharina Reisch, Maren Hein, Petra Kruse (N. Germany) and Andrea Podavkova and Gaute Myren (Norway) rendered technical assistance in conducting experiments and recording the data. 


\section{Authors' contributions}

RW and JB contributed equally to the analysis of data in Northern Germany and Norway, respectively; RW was the major contributor in writing. Both authors read and approved the final manuscript.

\section{Funding}

Open Access funding enabled and organized by Projekt DEAL. Our collaborative studies on fruit tree canker have been funded by The Research Council of Norway (projects FriskeTre in 2013-2015, and KreftKamp in 2017-2021).

\section{Availability of data and materials}

The datasets used and/or analysed during the current study are included in this article. Further information is available from the corresponding author upon reasonable request.

\section{Ethics approval and consent to participate}

Not applicable.

\section{Consent for publication}

Both authors and their institutions agree to publication.

\section{Competing interests}

The authors declare that they have no competing interests.

\section{Author details \\ ${ }^{1}$ Landwirtschaftskammer Niedersachsen, Esteburg Obstbauzentrum Jork, Moorende 53, 21635 Jork, Germany. ${ }^{2}$ Department of Food Science, Aarhus University, Agro Food Park 48, 8200 Aarhus, Denmark. ${ }^{3}$ Biotechnology and Plant Health Division, Norwegian Institute of Bioeconomy Research (NIBIO), PO Box 115, 1431 Ås, Norway.}

Received: 3 August 2020 Accepted: 12 January 2021

Published online: 25 January 2021

\section{References}

Agrios GN. Plant pathology. 5th ed. Amsterdam: Elsevier; 2005.

Alves SAM, Czermainski ABC. Controle do cancro Europeu das pomáceas com base no novo ciclo Neonectria ditissima-Macieira, nas condições do Brasil. Comunicado Técnico. 2015. https://doi.org/10.13140/RG.2.2.18495 .10 .404

Alves SAM, Nunes CC. Seasonal susceptibility of apple trees to Neonectria ditissima wound infections. N Z Plant Prot. 2017;70:73-7.

Amponsah NT, Walter M, Beresford RM, Scheper RWA. Seasonal wound presence and susceptibility to Neonectria ditissima infection in New Zealand apple trees. N Z Plant Prot. 2015;68:250-6.

Amponsah NT, Walter M, Scheper RWA, Beresford RM. Neonectria ditissima spore release and availability in New Zealand apple orchards. N Z Plant Prot. 2017a;70:78-86.

Amponsah NT, Scheper RWA, Fisher B, Walter M, Smits JM, Jesson LK. The effect of wood age on infection by Neonectria ditissima through artificial wounds on different apple cultivars. N Z Plant Prot. 2017b;70:97-105.

Bazzi C, Messina C, Tortoreto L, Stefani E, Bini F, Brunelli A, Andreotti C, Sabatini E, Spinelli F, Costa G, Hauptmann S, Stammler G, Doerr S, Marr J, Rademacher W. Control of pathogen incidence in pome fruits and other horticultural crop plants with prohexadione-Ca. Eur J Hort Sci. 2003;68:108-14

Børve J, Kolltveit SA, Talgø V, Stensvand A. Apple rootstocks may become infected by Neonectria ditissima during propagation. Acta Agric Scand B Soil Plant Sci. 2018:68:16-25.

Børve J, Dalen M, Stensvand A. Development of Neonectria ditissima infections initiated at grafting of apple trees. Eur J Plant Pathol. 2019;155:1225-39.

Bus VGM, Scheper RWA, Walter M, Campbell RE, Kitson B, Turner L, Fisher BM, Johnston SL, Wu C, Deng CH, Singla G, Bowatte D, Jesson LK, Hedderley DI, Volz RK, Chagné D, Gardiner SE. Genetic mapping of the European canker (Neonectria ditissima) resistance locus Rnd1 from Malus 'Robusta 5.' Tree Genet Genomes. 2019;15:25.

Campbell RE, Roy S, Curnow T, Walter M. Monitoring methods and spatial patterns of European canker disease in commercial orchards. N Z Plant Prot. 2016:69:213-20
Christensen OB, Goodess CM, Harris I, Watkiss P. European and global climate change projections. Discussion of climate change model outputs, scenarios and uncertainty in the EC RTD ClimateCost project. In: Watkiss P, editor. The ClimateCost project. Final report, vol 1: Europe. Stockholm: Stockholm Environment Institute; 2011. (ISBN 978-91-86125-35-6).

Cooke LR. The influence of fungicide sprays on infection of apple c $\mathrm{c}$ Bramley's seedling by Nectria galligena. Eur J Plant Pathol. 1999;105:783-90.

Cooke LR, Watters BS, Brown AE. The effect of fungicide sprays on the incidence of apple canker (Nectria galligena) in Bramley's Seedling. Plant Pathol. 1993;42:432-42.

Crane PE, Hopkins AJM, Dick MA, Bulman LS. Behaviour of Neonectria fuckeliana causing a pine canker disease in New Zealand. Can J For Res. 2009;39:2119-28

Creemers P. Nectria canker. In: Sutton TB, Aldwinckle HS, Agnello AM, Walgenbach JF, editors. Compendium of apple and pear diseases and pests. 2nd ed. St. Paul: APS; 2014. p. 49-51.

Cross J, Berrie A, Johnson D, Biddlecombe T, Pennell D, Luton M, Ashdown C. Apple best practice guide. Kenilworth: Agriculture and Horticulture Development Board; 2020. https://ahdbapples.azurewebsites.net. Accessed 25 Sept 2020.

Crowdy SH. Observations on apple canker. IV. The infection of leaf scars. Ann Appl Biol. 1952;39:569-80.

de Jong PF, van der Steeg PAH. Vruchtboomkanker in de vruchtboomkwekerij. Rapportnr. 2012-33 Wageningen: DLO; 2012. http://edepot.wur.nl/24585 6.

Dryden GH, Nelson MA, Smith JT, Walter M. Postharvest foliar nitrogen applications increase Neonectria ditissima leaf scar infection in apple trees. N Z Plant Prot. 2016;69:230-7.

Dubin HJ, English H. Factors affecting apple leaf scar infection by Nectria galligena conidia. Phytopathology. 1974;64:1201-3.

Flack NJ, Swinburne TR. Host range of Nectria galligena Bres. and the pathogenicity of some Northern Ireland isolates. Trans Brit Mycol Soc. 1977;68:185-92.

Garkava-Gustavsson L, Zborowska A, Sehic J, Rur M, Nybom H, Englund J-E, Lateur M, van de Weg E, Holefors A. Screening of apple cultivars for resistance to European canker Neonectria ditissima. Acta Hort. 2013;976:529-36

Gaskin RE, Manktelow DWL, Northcott GL. Effects of adjuvants on distribution and rainfastness of captan sprays on apple leaf scars to control European canker. N Z Plant Prot. 2014:67:139-44.

Ghasemkhani M, Sehic J, Ahmadi-Afzadi M, Nybom H, Garkava-Gustavsson L. Screening for partial resistance to fruit tree canker in apple cultivars. Acta Hort. 2015;1099:687-90

Gómez-Cortecero A, Saville RJ, Scheper RWA, Bowen JK, de Medeiros HA, Kingsnorth J, Xu X, Harrison RJ. Variation in host and pathogen in the Neonectria/Malus interaction; toward an understanding of the genetic basis of resistance to European canker. Front Plant Sci. 2016;7:1365.

Graf H. Versuche zur Wundbehandlung und Verhinderung der Sporulation von Krebswunden. Mitt Obstbauversuchsr Alt Land. 1976:31:150-3.

Graf H. Ein neues Kupferpräparat zur erfolgreichen Durchführung der Winterspritzungen gegen Obstbaumkrebs. Mitt Obstbauversuchsr Alt Land. 1985;40:103-11.

Hothorn T, Bretz F, Westfall P. Simultaneous inference in general parametric models. Biometr J. 2008;50:346-63.

Jansonius P, de Jong PF, Anbergen R. Vruchtboomkanker in de biologische vruchtboomteelt. Publicatie LF79. Driebergen: Louis Bolk Instituut; 2004.

Kennel W. Zur Pathogenese des Obstbaumkrebses (Nectria galligena Bres.) am Apfel. Gartenbauwissensch. 1963:28:29-64.

Kienzle J. Gesunderhaltung der Kulturpflanzen im ökologischen Apfelanbau. Weinsberg: $\mathrm{FÖKO} ; 2018$.

Klopp K, editor. Arbeitstagebuch für das Obstjahr. Esteburg-Obstbauzentrum Jork: Jork; 2020.

Krähmer H. Wundreaktionen von Apfelbäumen und ihr Einfluß auf Infektionen mit Nectria galligena. Zeitschr Pflanzenkrankh Pflanzensch. 1980;87:97-112.

Loewel EL, Saure M. Abwehrmaßnahmen gegen den Krebs vor und nach der Pflanzung. Mitt Obstbauversuchsr Alt Land. 1959;14:84-7. 
Lortie M, Kuntz JE. Ascospore discharge and conidium release by Nectria galligena Bres. under field and laboratory conditions. Can J Bot. 1963;41:1203-10

MacHardy WE. Apple scab biology, epidemiology, and management. St. Paul: APS; 1996.

Marsh RW. Observations on apple canker. II. Experiments on the incidence and control of shoot infections. Ann Appl Biol. 1939;26:458-69.

McCracken AR, Berrie A, Barbara DJ, Locke T, Cooke LR, Phelps K, Swinburne TR, Brown AE, Ellerker B, Langrell SRH. Relative significance of nursery infections and orchard inoculum in the development and spread of apple canker (Nectria galligena) in young orchards. Plant Pathol. 2003;52:553-66.

Munson RG. Observations on apple canker. I. The discharge and germination of spores of Nectria galligena Bres. Ann Appl Biol. 1939;26:440-57.

Orchard S, Campbell RE, Turner L, Butler RC, Curnow T, Patrick E, Walter M. Long-term deep-freeze storage of Neonectria ditissima conidium suspensions does not reduce their ability to infect apple trees. N Z Plant Prot. 2018;71:158-65.

Palm G. Untersuchungen zur Bekämpfung des Obstbaumkrebses (Nectria galligena, Bres.). Mitt Obstbauversuchsr Alt Land. 2009;64:180-5.

Palm G, Kruse P. Der Apfelmehltau - Möglichkeiten und Grenzen der mechanischen und chemischen Bekämpfung. Mitt Obstbauversuchsr Alt Land. 2010;65:148-51.

Palm G, Kruse P. Steht die Kupferminimierung im Widerspruch zu einer wirksamen Bekämpfung des Obstbaumkrebses? Mitt Obstbauversuchsr Alt Land. 2012;67:48-51.

Palm G, Harms F, Vollmer I. Mehrjährige Befallsentwicklung des Obstbaumkrebses an verschiedenen Apfelsorten an drei Standorten. Mitt Obstbauversuchsr Alt Land. 2011;66:360-3.

R Core Team. R: A language and environment for statistical computing. Vienna: R Foundation for Statistical Computing; 2020.

Saure M. Untersuchungen über die Voraussetzungen für ein epidemisches Auftreten des Obstbaumkrebses (Nectria galligena Bres.). Ph.D. diss., Tech Univ Berlin; 1961.

Saure M. Zur Anerkennung von Krebsheilmitteln im Obstbau. Erw-Obstb. 1962:4:35-6.

Saure M. Der Einfluß von Wuchshemmung und Wuchsförderung auf die Krebsanfälligkeit von Apfelbäumen. Mitt Obstbauversuchsr Alt Land. 1963;18:54-8

Saure M. Zur Prüfung von Spritzmitteln für die vorbeugende Bekämpfung des Obstbaumkrebses (Nectria galligena Bres.). Erwerbsobstb. 1965;7:232-4

Saure M. Woher kommt der Krebs in den Astwinkeln junger Apfelbäume? Mitt Obstbauversuchsr Alt Land. 1972;27:150-1.

Saure M. Möglichkeiten der Bekämpfung des Obstbaumkrebses (Nectria galligena Bres.). Mitt Obstbauversuchsr Alt Land. 1974;29:115-7.

Saville R, Olivieri L. Fungal diseases of fruit: apple cankers in Europe. In: Xu X, Fountain $M$, editors. Integrated management of diseases and insect pests of tree fruit. Cambridge: Burleigh Dodds; 2019. p. 59-84.

Scheper RWA, Stevenson O, Beresford R. Wound protection from European canker (Neonectria galligena) infection of apple in winter and autumn. J Plant Pathol. 2008;90(Suppl. 2):368.

Scheper RWA, Frijters L, Fisher BM, Hedderley DI. Effect of freezing of Neonectria ditissima inoculum on its pathogenicity. N Z Plant Prot. 2015;68:257-63.

Scheper RWA, Stevenson OD, Hedderley DI. Protection of budding wounds in apple nursery trees from European canker. N Z Plant Prot. 2016:69:151-7.

Scheper RWA, Fisher BM, Taylor T, Hedderley DI. Detached shoot treatments cannot replace wholetree assays when phenotyping for apple resistance to Neonectria ditissima. N Z Plant Prot. 2018:71:151-7.

Smith FD, MacHardy WE. The retention and redistribution of captan on apple foliage. Phytopathology. 1984;74:894-9.

Swinburne TR. The seasonal release of spores of Nectria galligena from apple cankers in Northern Ireland. Ann App Biol. 1971:69:97-104.

Swinburne TR. European canker of apple (Nectria galligena). Rev Plant Pathol. 1975:54:787-99.

Swinburne TR, Cartwright J, Flack NJ, Brown AE. The control of apple canker (Nectria galligena) in a young orchard with established infections. Ann Appl Biol. 1975;81:61-73.
Trese AT, Burton CL, Ramsdell DC. Eutypa armeniacae in Michigan vineyards: Ascospore production and survival, host infection, and fungal growth at low temperatures. Phytopathology. 1980;70:788-93.

Valdebenito-Sanhueza RM, da Boneti JIS, Alvez SAM. Cancro Europeu das pomáceas. J Fruta. 2012;20/257:17.

van der Scheer HAT. Bestrijding van vruchtboomkanker (Nectria galligena). Fruitteelt. 1974;64:1174-7.

Walter M, Stevenson OD, Amponsah NT, Scheper RWA, McLachlan ARG. Sensitivity of Neonectria ditissima to carbendazim fungicide in New Zealand. N Z Plant Prot. 2014;67:133-8.

Walter M, Glaister MK, Clarke NR, von Lutz H, Eld Z, Amponsah NT, Shaw NF. Are shelter belts potential inoculum sources for Neonectria ditissima apple tree infections? N Z Plant Prot. 2015a;68:227-40.

Walter M, Stevenson OD, Amponsah NT, Scheper RWA, Rainham DG, Hornblow CG, Kerer U, Dryden GH, Latter I, Butler RC. Control of Neonectria ditissima with copper based products in New Zealand. N Z Plant Prot. 2015b;68:241-9.

Walter M, Roy S, Fisher BM, Mackle L, Amponsah NT, Curnow T, Campbell RE, Braun P, Reineke A, Scheper RWA. How many conidia are required for wound infection of apple plants by Neonectria ditissima? N Z Plant Prot. 2016;69:238-45.

Walter M, Campbell RE, Amponsah NT, Turner L, Rainham D, Kerer U, Butler RC. Can biological products control Neonectria ditissima picking wound and leaf scar infections in apples? N Z Plant Prot. 2017a;70:63-72.

Walter M, Campbell RE, Amponsah NT, Scheper RWA, Butler RC. Evaluation of biological and agrichemical products for control of Neonectria ditissima conidia production. N Z Plant Prot. 2017b;70:87-96.

Walter M, Manktelow DWL, Le Berre F, Campbell RE, Turner L, Vorster L, Patrick E, Butler RC, Northcott GL. How much captan is required for wound protection of Neonectria ditissima conidial infection in apple? N Z Plant Prot. 2019;72:95-102

Weber RWS. Mikroskopische Methode zum Nachweis pathogener Pilze auf Fruchtmumien von Äpfeln. Erw-Obstb. 2012;54:171-6.

Weber RWS. Biology and control of the apple canker fungus Neonectria ditissima (syn. N. galligena) from a Northwestern European perspective. Erw-Obstb. 2014;56:95-107.

Weber RWS, Dralle N. Fungi associated with blossom-end rot of apples in Germany. Eur J Hortic Sci. 2013;78:97-105.

Weber RWS, Hahn A. Obstbaumkrebs und die Sorte 'Nicoter' (Kanzi $\left.{ }^{\circledR}\right)$ an der Niederelbe. Mitt Obstbauversuchsr Alt Land. 2013:68:247-56.

Weber RWS, Klopp K. Nectria galligena as the cause of a collar rot disease in organically grown Topaz apple trees. In: Proceedings 12th internat conf on cultivation technique and phytopathological problems in organic fruit-growing. Weinsberg: FÖKO; 2006. p. 121-4. http://www.ecofruit. net/2006/ecofruit_12th_21-1.pdf. Accessed 25 Sept 2020.

Weber RWS, Kruse P. Fungizide gegen Apfelschorf im Kontext aktueller Behandlungsempfehlungen. Mitt Obstbauversuchsr Alt Land. 2018;73:127-34.

Weber RWS, Palm G. Resistance of storage rot fungi Neofabraea perennans, N. alba, Glomerella acutata and Neonectria galligena against thiophanatemethyl in Northern German apple production. J Plant Dis Protect. 2010;117:185-91.

Weber RWS, Kruse P, Børve J. Frukttrekreft 7: Kjemisk kontroll av infeksjonar på greiner. Norsk Frukt Bær. 2019;22(2):12-4.

Wenneker M, de Jong PF, Joosten NN, Goedhart PW, Thomma BPHJ. Development of a method for detection of latent European fruit tree canker (Neonectria ditissima) infections in apple and pear nurseries. Eur J Plant Pathol. 2017;148:631-5

Wessel H. Sporenfreisetzung bei Nectria galligena Bres in ErwerbsAnlagen des Niederelbischen Obstanbaugebietes 1977. Erw-Obstb. 1979;21:196-201

Westerlaken J, van Dijke J. Resultaten bestrijdingsproeven vruchtboomkanker. Fruitteelt. 1987;77(45):9-11.

Wood PN, Beresford RM. Avoiding apple bud damage from autumnapplied urea for black spot (Venturia inaequalis) control. N Z Plant Prot. 2000;53:382-6.

Xu X-M, Robinson JD. Effects of fruit maturity and wetness on the infection of apple fruit by Neonectria galligena. Plant Pathol. 2010;59:542-7. 
Xu X-M, Butt DJ, Ridout MS. The effects of inoculum dose, duration of wet period, temperature and wound age on infection by Nectria galligena of pruning wounds on apple. Eur J Plant Pathol. 1998;104:511-9.

Xu X-M, Murray RA, Salazar JD, Hyder K. The effects of temperature, humidity and rainfall on captan decline on apple leaves and fruit in controlled environment conditions. Pest Manag Sci. 2008;64:296-307.

Yoder KS, Miller SS, Byers RE. Suppression of fireblight in apple shoots by prohexadione-calcium following experimental and natural inoculation. HortSci. 1999:34:1202-4.

Zabel D. Die Krebsepidemie 2010 und ihre Ursachen. Ergebnisse einer Befragung zur Situation der Sorte 'Kanzi'. Mitt Obstbauversuchsr Alt Land. 2011:66:218-22.
Zhang Q, Karkee M, Tabb A. The use of agricultural robots in orchard management. In: Billingsley J, editor. Robotics and automation for improving agriculture. Cambridge: Burleigh Dodds; 2019. p. 187-214.

\section{Publisher's Note}

Springer Nature remains neutral with regard to jurisdictional claims in published maps and institutional affiliations.
Ready to submit your research? Choose BMC and benefit from:

- fast, convenient online submission

- thorough peer review by experienced researchers in your field

- rapid publication on acceptance

- support for research data, including large and complex data types

- gold Open Access which fosters wider collaboration and increased citations

- maximum visibility for your research: over $100 \mathrm{M}$ website views per year

At BMC, research is always in progress.

Learn more biomedcentral.com/submissions 